\title{
An integrated wastewater treatment system using a BAS reactor with biomass attached to tubular supports
}

\author{
Antonella Luciano ${ }^{\mathrm{a}, *}$, Paolo Viotti ${ }^{\mathrm{a}}$, Giuseppe Mancini ${ }^{\mathrm{b}}$, Vincenzo Torretta ${ }^{\mathrm{c}}$ \\ a Department of Civil, Building and Environmental Engineering (DICEA), Sapienza University of Rome, Via Eudossiana 18, I-00184 Rome, Italy \\ ${ }^{\mathrm{b}}$ Department of Industrial and Mechanical Engineering, University of Catania, Via A. Doria 6, I-95125 Catania, Italy \\ ${ }^{\mathrm{c}}$ Department of Science and High Technology, Insubria University of Varese, Via G.B. Vico 46, I-21100 Varese, Italy
}

\section{A R T I C L E I N F O}

Article history:

Received 23 April 2012

Received in revised form 8 August 2012

Accepted 23 August 2012

Available online

\section{Keywords:}

Compact wastewater treatment system

Attached biomass

Biofilm airlift suspension reactor

Denitrification

Nitrification

\begin{abstract}
A B S T R A C T
This paper describes laboratory experiments aimed to develop a new wastewater treatment system as an alternative to a conventional domestic wastewater plant. A modified Biofilm Airlift Suspension reactor (BAS), with biomass attached to tubular supports, is proposed to address low organic loads (typical of domestic sewage) and low residence time (typical of compact reactors technology). Attached and suspended biomasses, coupled to the high dissolved oxygen (DO), allow high removal efficiencies ( $90 \%$ and $56 \%$ for $\mathrm{COD}$ and $\mathrm{N}-\mathrm{NH}_{4}^{+}$removal respectively) and high effluent quality to be reached. The experimental activity, divided into three parts, demonstrates the good efficiency of the process, and the reduction of the removal kinetics for the high operating pressure used in the technology. The occurrence of simultaneous nitrification-denitrification (SND) was also observed. When compared with the conventional BAS system, the present treatment shows comparable removal efficiencies and higher specific removal rates ( $80 \mathrm{mg} \mathrm{COD} / \mathrm{g}$ VSS and $2.60 \mathrm{mg} \mathrm{N}-\mathrm{NH}_{4}^{+} / \mathrm{g}$ VSS). The experimental results were coupled with the development of a numerical model to aid in designing a full-scale treatment plant in Italy.
\end{abstract}

(C) 2012 Published by Elsevier Ltd.

\section{Introduction}

High effluent quality standards, such as those required by recent European regulations, and restrictive indexes for water quality (Verlicchi et al., 2011), coupled with the increasing economic value of land surrounding large cities, have led to a growing interest in developing alternative wastewater treatment solutions with smaller surface area requirements. The need for new wastewater treatment processes is further intensified by the increased attention and intolerance of urban communities for the main impacts of wastewater treatment plants, such as odor and noise.

Conventional wastewater treatment plants (WWTPs), which utilize suspended biomass only, are well known, widely tested and generally considered reliable. However, there are many potential issues related to the management of these plants: first, they require onerous process controls due to the sensitivity of the biomass to organic and hydraulic load variability, and second, a large surface area is generally required for WWTPs, making limited area availability another critical issue.

\footnotetext{
* Corresponding author. Tel.: +39 (0) 644585067; fax: +39 (0) 644585512.

E-mail address: antonella.luciano@uniroma1.it (A. Luciano).
}

These issues can be overcome with biofilm systems. Microbial cell aggregates (in the form of either flocks or biofilms) have generated great interest in wastewater treatment due to their advantages when compared to conventional dispersed biomass treatments, e.g., easier cell-liquid separation by sedimentation or filtration, the absence of sludge recycling, lower excess sludge production and the ability to better withstand higher organic loads per unit volume (Nicolella et al., 2000a). In biofilm reactors, the biomass can metabolize the substrate with short residence times, which results in compact reactors with smaller area requirements. In these systems, the oxygen delivery to the liquid phase, rather than the biomass concentration, is the limiting factor (Nicolella et al., 2000b, 1998; Tomaszek and Grabas, 1998). The low oxygen concentrations in the inner region of the biofilm (due to the limited diffusion of oxygen through the biofilm and consumption of oxygen by the aerobic reactions) stratify the biofilm into two zones: an aerated outer zone and an anoxic deeper zone. This stratification can lead to the removal of the nitrates by denitrification. "Simultaneous nitrification and denitrification" (SND) in a single reactor has been tested using different methods, such as using a flexible biofilm reactor with an adjustable aerobic buffer and anoxic zones (Guo et al., 2005; Zhang et al., 2007); a biofilm airlift suspension reactor operating with film-covered biodegradable carriers (Walters et al., 2009); a fixed-film reactor with different aerobic, 


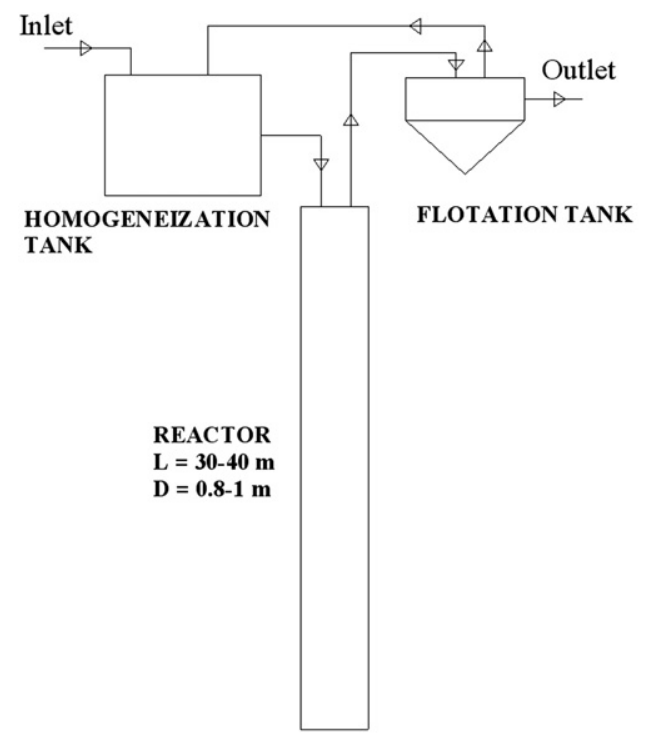

a

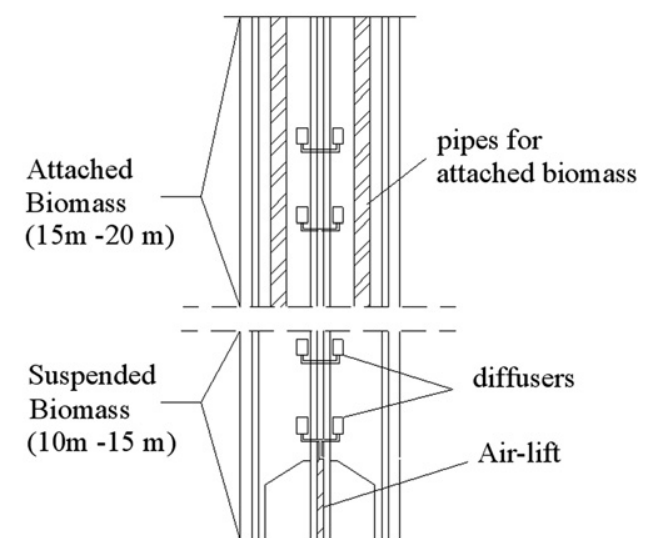

b

Fig. 1. Full-scale plant. a) schematic diagram; b) particulars of the reactor.

transition and anoxic zones (Del Pozo and Diez, 2005); or other types of integrated bioreactors (Li et al., 2010). If well operated, the SND process can reduce the reactor volume and the recirculation energy cost required by the more traditional systems that use separate aerobic and anoxic processes. In case of wastewater reuse, high performance in denitrification could not be necessary (Mancini et al., 2007).
In this paper, the performance of a compact system that combines the advantages of attached and suspended biomass was investigated. Fig. 1 shows the layout of the entire plant. The homogenization tank precedes the reactor, which incorporates biofilm airlift suspension (BAS). The upper part of the reactor is equipped with a series of rough pipes, allowing for growth of the biofilm. Suspended biomass is present in the deeper part of the

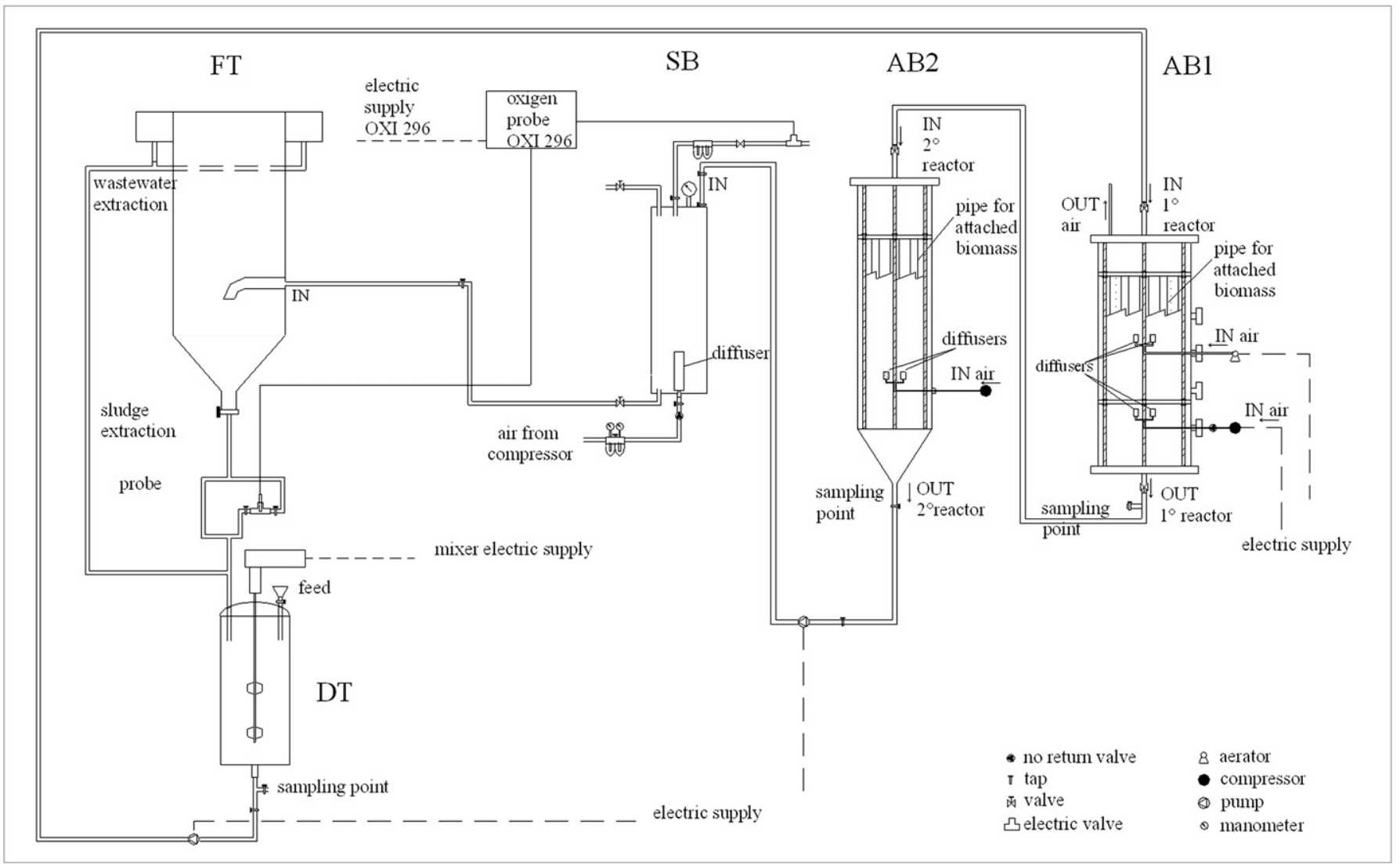

Fig. 2. Layout of the experimental setup. 
Table 1

Operating conditions for all the six experiments.

\begin{tabular}{llllllll}
\hline Test & $\begin{array}{l}\mathrm{COD} \\
(\mathrm{mg} / \mathrm{l})\end{array}$ & $\begin{array}{l}\mathrm{N}-\mathrm{NH}_{4}^{+} \\
(\mathrm{mg} / \mathrm{l})\end{array}$ & $\begin{array}{l}\mathrm{HRT} \\
(\mathrm{h})\end{array}$ & $\begin{array}{l}\mathrm{T} \\
\left({ }^{\circ} \mathrm{C}\right)\end{array}$ & $\mathrm{pH}$ & $\begin{array}{l}\mathrm{DO} \\
(\mathrm{mg} / \mathrm{l})\end{array}$ & $\begin{array}{l}\mathrm{P} \\
(\text { bar })\end{array}$ \\
\hline 1.A - reactor & 226 & 14 & 6 & 18.9 & 7.8 & 18.0 & 2.0 \\
1.B - reactor & 218 & 15 & 6 & 20.8 & 8.2 & 36.0 & 4.0 \\
$1 . \mathrm{C}-$ reactor & 238 & 12 & 6 & 20.0 & 8.2 & 49.0 & 5.5 \\
1.A - batch & 226 & 14 & 6 & 18.0 & 8.0 & $9.0^{\mathrm{a}}$ & 1.0 \\
1.B - batch & 218 & 15 & 6 & 17.2 & 8.6 & $9.0^{\mathrm{a}}$ & 1.0 \\
1.C - batch & 238 & 12 & 6 & 19.0 & 8.6 & $9.0^{\mathrm{a}}$ & 1.0 \\
\hline
\end{tabular}

a Stirred conditions.

Table 2

Wastewater characteristics.

\begin{tabular}{lcc}
\hline Parameter & Wastewater 1 & Wastewater 2 \\
\hline $\mathrm{pH}$ & $7.8-8.4$ & $8.2-8.4$ \\
$\mathrm{COD}(\mathrm{mg} / \mathrm{l})$ & $218-238$ & $590-610$ \\
$\mathrm{BOD} 5(\mathrm{mg} / \mathrm{l})$ & $109-119$ & $328-339$ \\
$\mathrm{TN}(\mathrm{mg} / \mathrm{l})$ & $12-15$ & $31-66$ \\
BOD5/N & $8-9$ & $5-10$ \\
\hline
\end{tabular}

reactor. An airlift is used to raise the wastewater and the sludges (both attached and suspended) to a floating section.

The suspended biomass can be re-circulated to the homogenization tank. Over the course of a complete cycle, the suspended biomass is subjected to high pressures coupled with a quick change in the operating conditions. This biomass acts as a finishing treatment and can therefore modify its behavior when subjected to such stresses. Several researchers are focused on the performance of BAS reactors (Garrido et al., 1997; Ong et al., 2004; Tijhuis et al., 1996; Zhou et al., 2003); however, few studies have analyzed the influence of high pressure on the process kinetics. This experimental study devotes specific attention to the effects of increased operational pressures on the kinetics of the biological reaction.

\section{Materials and methods}

\subsection{Experimental setup}

A bench-scale plant simulating the attached biomass-deep reactor was designed as sequence of different process units, as illustrated in Fig. 2.

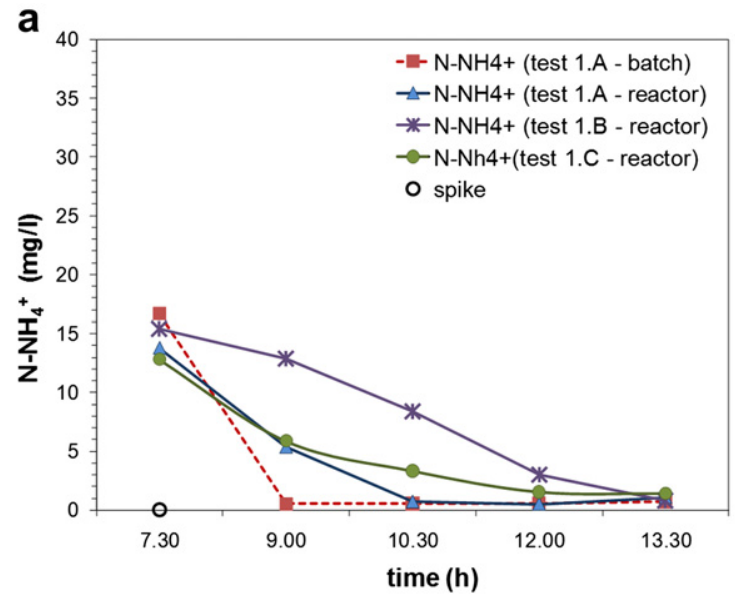

The experimental setup included the following:

- A homogenization tank with a mixer (DT);

- Two attached biomass aerated reactors in series (AB1 and AB2), reproducing the upper part of the system;

- A suspended biomass pressurized reactor (SB) (2-5 bar) with oxygen diffusers, reproducing the deeper part of the reactor;

- A tank for the flotation of the reactor outflow (FT);

- Probes for the measurement of the dissolved oxygen concentration (OXM) in the different sections.

The first unit of the bench-scale plant (DT) is $50 \mathrm{~cm}$ high and has a circular cross-section with a $22 \mathrm{~cm}$ diameter. A static mixer is used to maintain suspension of the biomass.

The $A B 1$ reactor is composed of a column made from Plexiglas with a height of $60 \mathrm{~cm}$ and an outer diameter of $25 \mathrm{~cm}$. Four equally spaced ports are located along the column: the upper two are used for sampling (H30, H40) and the lower two are used as air inlets. The aeration system consists of two sets of four diffusers located at two different levels within the reactor. The aeration system allowed having DO concentrations values comprised between 6 and $7 \mathrm{mg} / \mathrm{l}$. The lower set of diffusers is also used for the periodic detachment of biomass that can be achieved by using a pulse of air with a higher flowrate. Nine PVC pipes $(D=2.6 \mathrm{~cm}$ and $H=30 \mathrm{~cm}$ ) are located inside the reactor to act as a support for biofilm growth. The pipes are slightly rough to improve the attachment conditions.

The $A B 2$ reactor $(D=20 \mathrm{~cm}, H=80 \mathrm{~cm})$ is connected in series to the $A B 1$ reactor and has similar characteristics. Three sampling outlets are located along the length of the AB2 reactor; the lowest outlet is used for air injection.

Both the $A B 1$ and $A B 2$ reactors are sealed to maintain pressure levels that are typical in the upper part of the reactor (1-2 bar).

The subsequent SB reactor is designed to reproduce the increasing pressure levels in the range of those occurring in the deeper part of a full-scale reactor (2-5 bars). The SB reactor consists of a steel cylinder with a diameter of $15 \mathrm{~cm}$, a height of $1 \mathrm{~m}$ and a total volume of $17 \mathrm{l}$ ( $7 \mathrm{l}$ when operated at high pressures). Oxygen is provided by an internal diffuser feed from a compressor. Several probes are used to control the DO levels, pressure inside the reactor and flowrate, which is used to compute the hydraulic retention time (HRT).

b

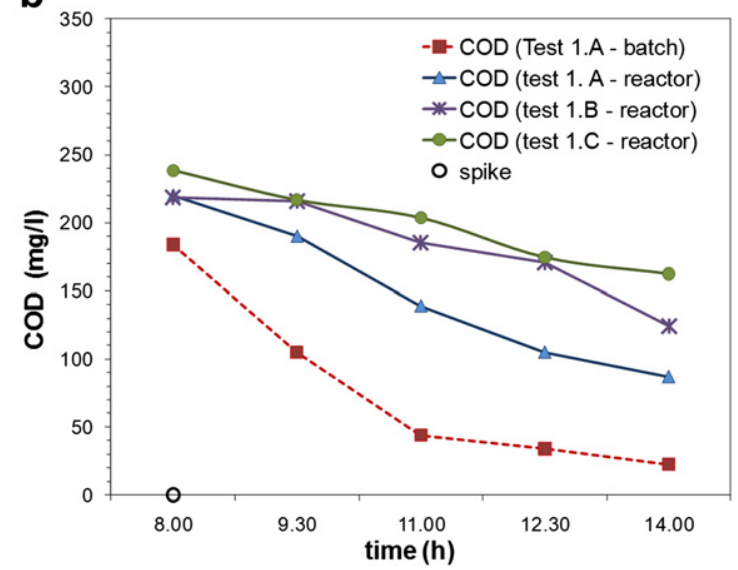


Table 3

Specific removal rates for $\mathrm{N}-\mathrm{NH}_{4}^{+}$and $\mathrm{COD}$ at different pressures and for different contact times.

\begin{tabular}{|c|c|c|c|c|c|c|c|c|c|c|c|}
\hline \multirow[t]{2}{*}{ Test } & \multirow[t]{2}{*}{$\mathrm{P}($ bar $)$} & \multicolumn{5}{|c|}{$\mathrm{N}-\mathrm{NH}_{4}^{+}$specific removal rate $\left(\mathrm{mg} \mathrm{N}-\mathrm{NH}_{4}^{+} / \mathrm{g} \mathrm{SSV} \mathrm{h}\right)$} & \multicolumn{5}{|c|}{ COD specific removal rate (mg COD/g SSV h) } \\
\hline & & $0-1 \mathrm{~h}$ & $1-3 \mathrm{~h}$ & $3-4.5 \mathrm{~h}$ & $4.5-6 \mathrm{~h}$ & Total & $0-1 \mathrm{~h}$ & $1-3 \mathrm{~h}$ & $3-4.5 \mathrm{~h}$ & $4.5-6 \mathrm{~h}$ & Total \\
\hline 1.A - batch & 1 & 4.7 & 0.0 & 0.0 & 0.0 & 1.1 & 31.9 & 26.4 & 4.9 & 4.2 & 16.9 \\
\hline 1.A - reactor & 2 & 3.8 & 2.2 & 0.1 & 0.0 & 1.7 & 13.5 & 24.1 & 17.6 & 10.3 & 17.5 \\
\hline 1.B - reactor & 4 & 1.3 & 2.8 & 3.6 & 1.5 & 2.1 & 1.2 & 18.7 & 9.8 & 30.8 & 13.2 \\
\hline 1.C - reactor & 5.5 & 4.2 & 1.6 & 1.2 & 0.1 & 1.7 & 13.3 & 8.1 & 18.8 & 9.2 & 11.3 \\
\hline
\end{tabular}

A pressure-reducing valve is used to regulate the flow to the floating tank (FT), where the excess of air allows for separation of the solid from the liquid. The residual biomass flocks are further separated in the sedimentation tank.

\subsection{Experiments}

The experimental approach consisted of three phases. The first phase aimed at testing the influence of high pressures, typical of the deeper part of the reactor, on the activity of the suspended biomass. The second phase studied the removal efficiency of the attached biomass. These two experimental phases were conducted in two different sub-sections of the experiment. The third phase aimed at verifying the combination of the suspended and attached biomass on the overall efficiency.

The experimental results, coupled with the development of a numerical model, were applied to aid in the complete design of a full-scale treatment plant realized in Italy.

\subsubsection{First experimental phase}

In this phase, the behavior of the suspended biomass under stressed conditions was investigated. The batch experiments were performed using only the SB reactor, equipped with a recycling system that allowed for water sampling and the measurement of dissolved oxygen (DO) concentrations. Pressurized operating conditions were achieved by insufflating air by means of a compressor.

Three batch tests (1.A reactor, 1.B reactor, 1.C reactor) were conducted under different pressure conditions ( 2 bar, 4 bar and 5.5 bar) for an HRT of $6 \mathrm{~h}$. The resulting substrate removal rates were compared with those obtained through the three corresponding experiments performed at atmospheric pressure (1.A batch, 1.B batch, 1.C batch). Table 1 shows the characteristics of the influent feed and the operating conditions of all six experiments. The $\mathrm{pH}$ ranged from 7.8 to 8.4. The temperature differences between the batch and reactor tests were due to the energy needed to achieve the required operating conditions in the reactor.

Wastewater 1 (Table 1 ) was used as the feed. The COD, $\mathrm{N}-\mathrm{NH}_{4}^{+}$, $\mathrm{NO}_{3}^{-}, \mathrm{NO}_{2}^{-}$, and $\mathrm{SS}$ were measured at fixed times. The specific rate of substrate removal and the mass balances for the various substrates were calculated for all of the tests. Microbiological assays that were derived from the two test conditions (atmospheric and high pressures) were also performed on the biomass.

\subsubsection{Second experimental phase}

The aim of the second experimental phase was to investigate the processes occurring in the attached biomass section of the reactor. The setup for this phase consisted of two reactors, AB1 and AB2 (as previously described), and the clarifier (FT) from which the wastewater was re-circulated at the inlet. In the proposed scheme, the attached biomass would grow on the inert supports (pipes with rough surfaces). The behavior of the attached biomass was observed during the growth and detachment phases under nonlimiting dissolved oxygen (DO) conditions in the liquid phase of the reactor.

The system was initially inoculated with biomass derived from a full-scale wastewater treatment plant. Tests were performed after 10 days, which is the time necessary for biomass development and for stabilization of the $\mathrm{COD}$ and $\mathrm{N}-\mathrm{NH}_{4}^{+}$removal efficiencies. Wastewater 2 (Table 2) was used as feed for the reactor.
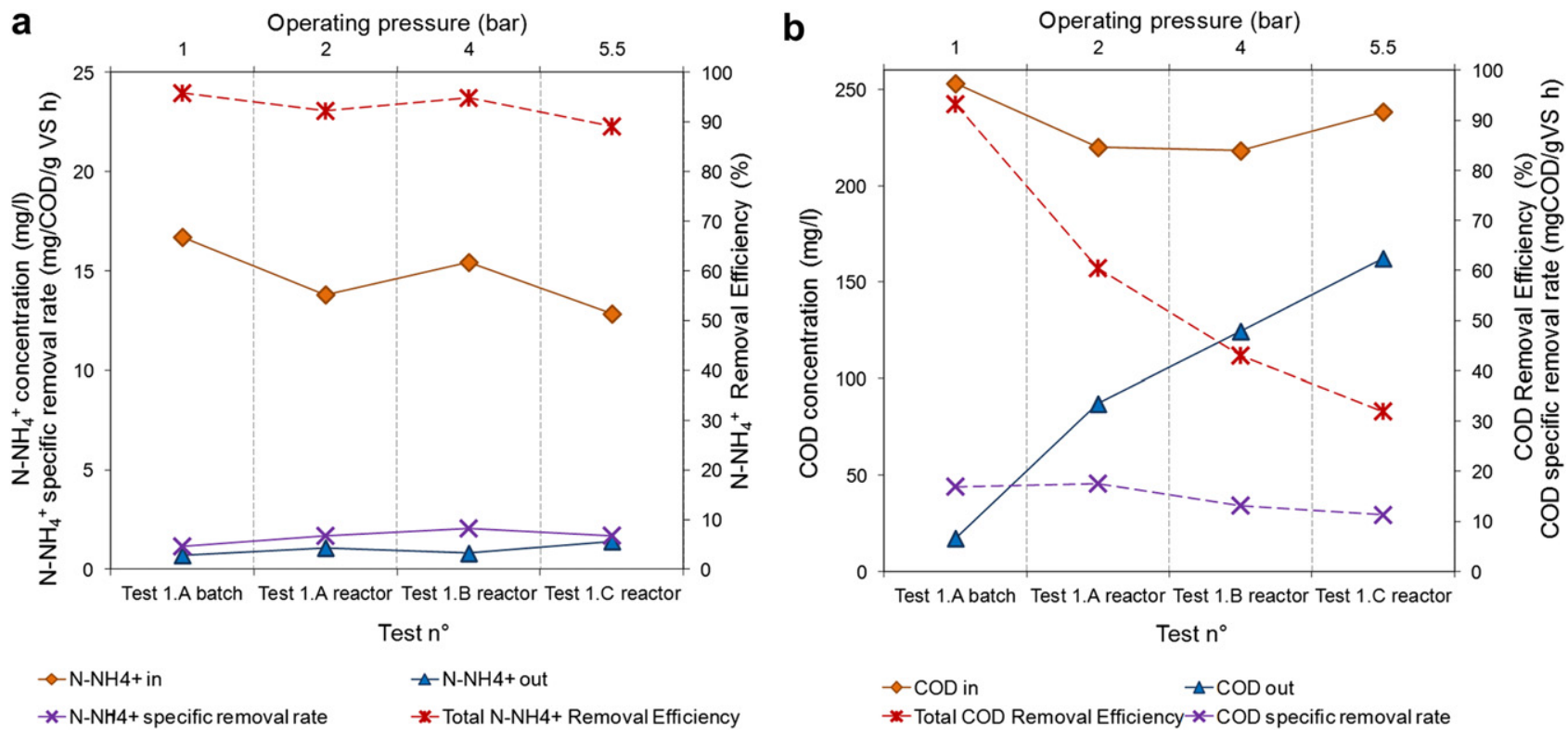

Fig. 4. Substrate removal efficiencies and specific removal rates for a) $\mathrm{N}-\mathrm{NH}_{4}^{+}$and b) COD. 


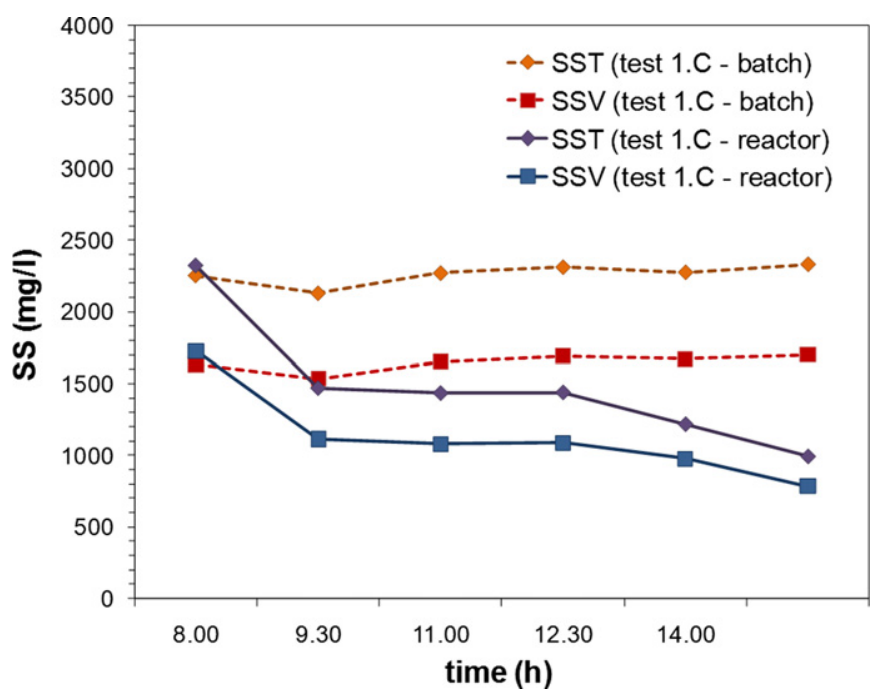

Fig. 5. SST and SSV at atmospheric pressure (Test $1 . \mathrm{C}$ - batch) and at 5.5 bar (Test 1.C reactor).

The entire experiment lasted 83 days for a total of 15 runs. Each run consisted of the following steps:

1. The substrate was spike-added.

2. The system was run for an HRT of four hours, and samples were collected every hour.

3. The system was emptied and refilled for the following run.

Detachment was performed after every $3-4$ runs by increasing in the air flow.

The biofilm thickness, typology, and growth and re-growth rates were continuously controlled, and microbiological analyses were performed. The effectiveness of the detachment system and the regrowth phases were also analyzed. These controls were performed inserting removable supports at different height in the reactor. Two samples were collected for each test (run) for a total amount of 32 samples.

\subsubsection{Third experimental phase}

In the third experimental phase, the complete system (Fig. 2), which reproduces the hypothesized treatment system with all its components, was implemented.

The start-up of the system was performed with the same procedure described for the second experimental phase. After the biomass was acclimated, the reactor was operated for 53 days and four tests were performed. Wastewater 2 and wastewater 1 (Table 2) were used as influent substrates for the first three tests and for the last test, respectively. Two measurements of biofilm thickness were performed for each test, using removable supports inserted at different height in the reactor, for a total amount of 8 measurements.

\subsection{Wastewater characteristics}

In all the three experimental phases, the system was inoculated with activated sludge taken from the oxidation reactor of a full-scale WWTP. Domestic wastewater derived from two treatment plants in Rome, collected after grit removal, was used as the feed. The average composition of the two wastewaters is shown in Table 2.

\subsection{Analytical methods}

$\mathrm{COD}, \mathrm{N}-\mathrm{NH}_{4}^{+}, \mathrm{NO}_{3}^{-}, \mathrm{NO}_{2}^{-}$, and $\mathrm{SS}$ were determined according to standard methods (Eaton et al., 2005). Water pH, temperature and DO were measured with standard probes. The biofilm thickness was monitored using a microscope with removable supports inserted at different heights in the reactor. Microbiological analysis was carried out by analyzing fresh sludge by means of electronic microscope while for a more detailed characterization colorimeter techniques (Gram and Neisser) were used.

\section{Results and discussion}

\subsection{Results from the first experimental phase}

\subsubsection{Effects of increased pressure on nitrogen and carbonaceous} substrate removal

Fig. 3 shows the substrates concentration $\left(\mathrm{N}-\mathrm{NH}_{4}^{+}, \mathrm{COD}\right)$ versus time for all of the performed tests, providing information on the

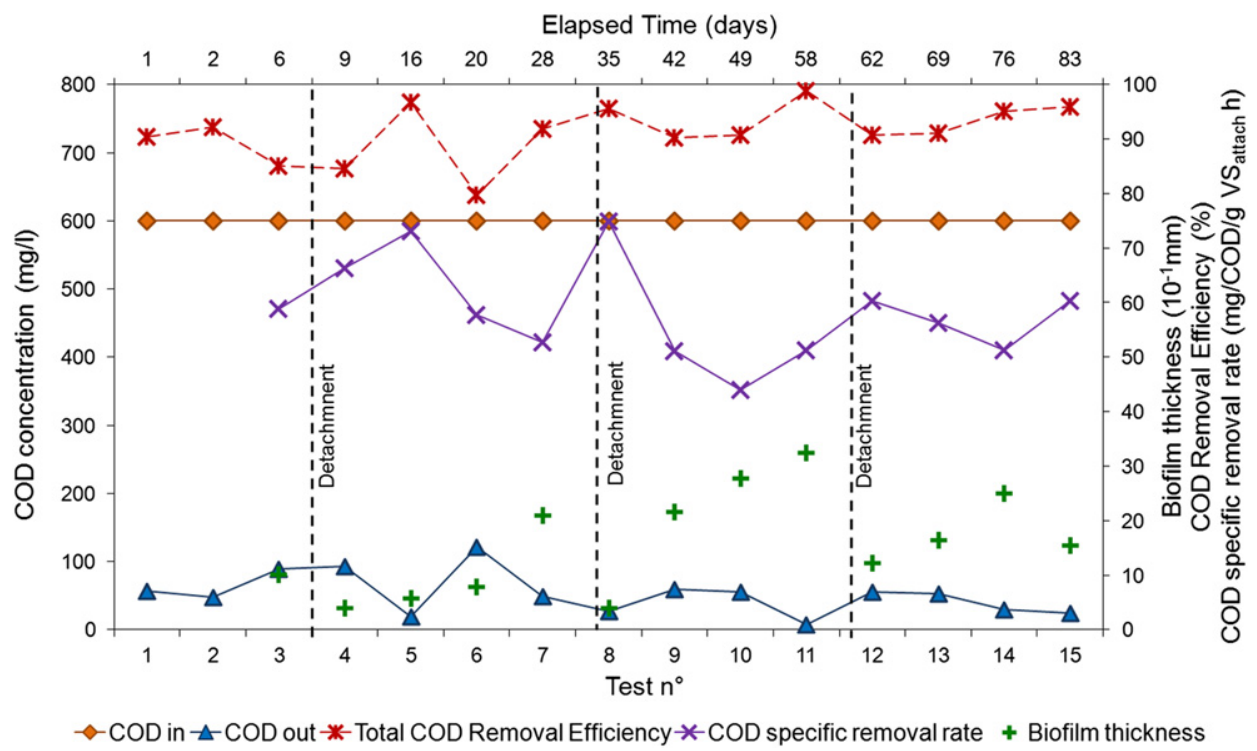

Fig. 6. COD concentrations (influent and effluent), removal efficiency, specific removal rates and biofilm thickness in the attached biomass section (reactors $A B 1$ and $A B 2$ ). 
Table 4

COD specific removal rates in the attached biomass section ( $A B 1$ and $A B 2$ ).

\begin{tabular}{|c|c|c|c|c|c|c|c|c|c|c|}
\hline \multirow[t]{2}{*}{ Test } & \multirow[t]{2}{*}{ Day } & \multirow{2}{*}{$\begin{array}{l}\text { Biofilm } \\
\text { thickness (mm) }\end{array}$} & \multirow[t]{2}{*}{ VS $(g / l)$} & \multicolumn{7}{|c|}{ COD specific removal rate (mg COD/g VS attach $\mathrm{h}$ ) } \\
\hline & & & & $0-0.5 \mathrm{~h}$ & $0.5-1.25 \mathrm{~h}$ & $1.25-2 \mathrm{~h}$ & $2-2.75 \mathrm{~h}$ & $2.75-3.5 \mathrm{~h}$ & $3.5-4.25 \mathrm{~h}$ & Total \\
\hline 1 & 1 & & & & & & & & & \\
\hline 2 & 2 & & & & & & & & & \\
\hline 3 & 6 & 1.015 & 2.041 & 218.4 & 71.3 & 45.4 & 29.2 & 16.2 & 25.9 & 58.9 \\
\hline 4 & 9 & 0.40 & 1.801 & 214.0 & 106.6 & 36.1 & 25.3 & 28.9 & 36.1 & 66.3 \\
\hline 5 & 16 & 0.57 & 1.869 & 325.1 & 107.3 & 38.1 & 27.7 & 13.9 & 10.4 & 73.1 \\
\hline 6 & 20 & 0.79 & 1.953 & 186.9 & 82.8 & 33.1 & 36.5 & 43.1 & 6.6 & 57.7 \\
\hline 7 & 28 & 2.10 & 2.461 & 90.1 & 139.0 & 28.9 & 36.7 & 28.9 & 5.2 & 52.7 \\
\hline 8 & 35 & 0.40 & 1.802 & 212.8 & 148.4 & 50.7 & 57.9 & 18.1 & 7.2 & 74.8 \\
\hline 9 & 42 & 2.17 & 2.489 & 182.8 & 52.5 & 28.9 & 49.9 & 26.3 & 10.5 & 51.2 \\
\hline 10 & 49 & 3.25 & 2.909 & 220.2 & 60.2 & 11.2 & 22.3 & 6.7 & 2.2 & 44.0 \\
\hline 11 & 58 & 2.78 & 2.723 & 167.9 & 90.3 & 30.9 & 21.4 & 14.3 & 21.4 & 51.2 \\
\hline 12 & 62 & 1.23 & 2.125 & 265.5 & 70.1 & 54.8 & 6.1 & 24.4 & 9.1 & 60.3 \\
\hline 13 & 69 & 1.65 & 2.288 & 316.5 & 11.3 & 17.0 & 42.4 & 31.1 & 5.7 & 56.2 \\
\hline 15 & 83 & 1.55 & 2.248 & 297.5 & 57.3 & 28.7 & 34.4 & 11.5 & 11.5 & 60.3 \\
\hline Mean & & 1.57 & 2.256 & 215.5 & 78.3 & 32.1 & 30.4 & 20.6 & 12.0 & 55.95 \\
\hline
\end{tabular}

substrate removal rate, removal efficiency and residual concentration. The comparison is shown only for one of the three experiments at atmospheric pressure because of the similarity of the results.

At atmospheric pressure (Test 1.A Batch), the nitrogen ion concentration approaches zero at the first sampling, indicating that the ammonia conversion was largely completed in the first $1.5 \mathrm{~h}$. In the reactor, however, the same ammonia conversion is achieved after a longer period ( $3 \mathrm{~h}$ at 2 bar and $5-6 \mathrm{~h}$ at pressures higher than 2 bar, Fig. 3a). Specific removal rates, calculated by dividing the removal rates by the measured concentrations of the volatile solids (VS), are reported in Table 3 for all of the tests.

The total $\mathrm{N}-\mathrm{NH}_{4}^{+}$and $\mathrm{COD}$ removal efficiencies and specific removal rates are reported in Fig. 4. In comparison to the batch test, lower substrate removal rates were observed in the reactor. However, no inhibitory effects were detected for all of the conditions. The total $\mathrm{N}-\mathrm{NH}_{4}^{+}$removal efficiencies in the reactor were also high (92\% at $P=2$ bar, $95 \%$ at $P=4$ bar and $89 \%$ at $P=5.5$ bar) and comparable with the removal efficiency at atmospheric pressure (96\%). The total specific removal rates were also significantly high even at higher pressures.
The soluble COD showed a different behavior from the $\mathrm{N}-\mathrm{NH}_{4}^{+}$: after six hours of hydraulic residence time, the COD concentration in the reactor (Fig. $3 \mathrm{~b}$ ) was still high, leading to lower removal efficiencies for increasing pressure levels (Fig. 4b). The COD removal rates slightly decreased with the increase in pressure (Fig. 4b).

From these results, it was clear that high pressure conditions can significantly influence the removal rates for the suspended biomass even if the high pressures do not produce an overall inhibitory effect.

Some conclusions can also be drawn from the reduction in the concentration of the total and volatile solids at the higher pressures (Fig. 5). Fig. 5 shows the SST and SSV concentrations at the two extreme conditions (atmospheric pressure and 5.5 bar). In the high pressure case, a lower concentration of biomass and a reduction of the floc dimensions can be observed in the reactor, indicating the effect of high pressure on floc disaggregation.

\subsubsection{Microbiological biomass characteristics}

Microbiological assays were performed on the biomass samples taken from the two different test conditions. Differences were

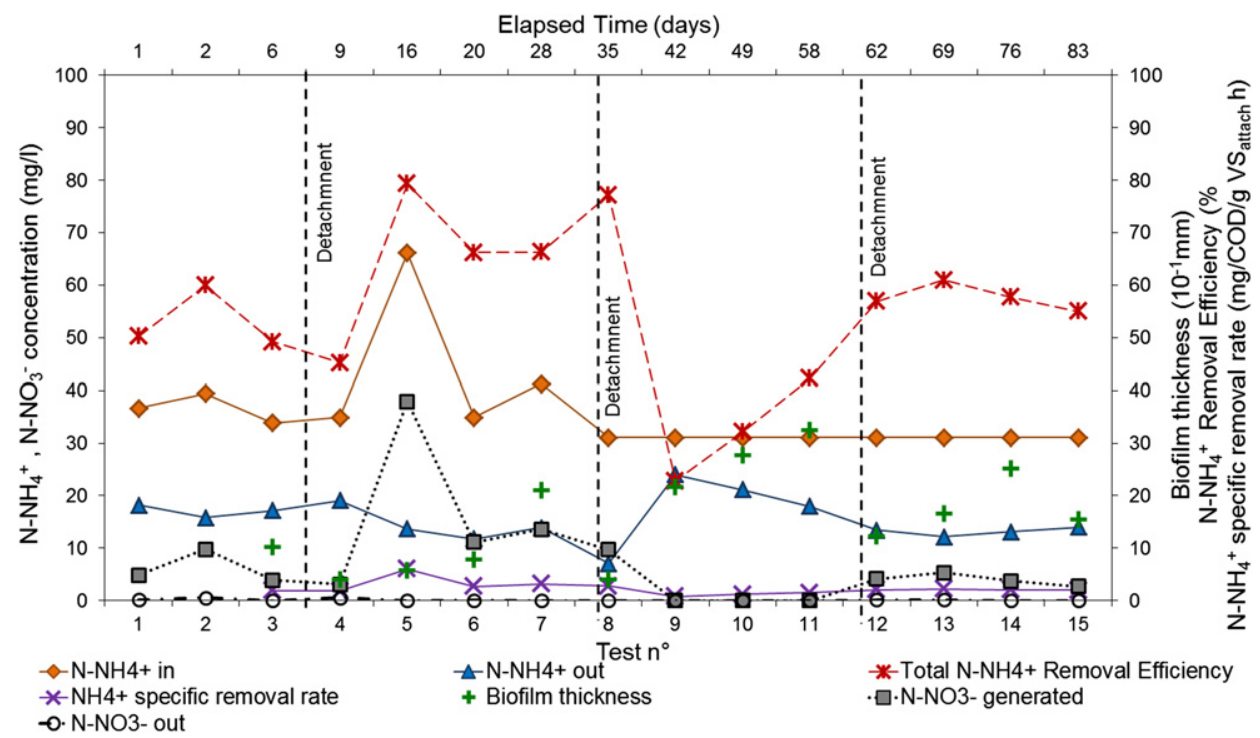

Fig. 7. $\mathrm{N}-\mathrm{NH}_{4}^{+}$concentrations (influent and effluent), removal efficiency, specific removal rates and biofilm thickness in the attached biomass section (reactors $\mathrm{AB} 1$ and $\mathrm{AB} 2$ ). 
Table 5

Specific removal rates of $\mathrm{N}-\mathrm{NH}_{4}^{+}$in the attached biomass section ( $\mathrm{AB} 1$ and $\mathrm{AB} 2$ ).

\begin{tabular}{|c|c|c|c|c|c|c|c|c|}
\hline \multirow[t]{2}{*}{ Test } & \multirow[t]{2}{*}{ Day } & \multicolumn{7}{|c|}{$\mathrm{N}-\mathrm{NH}_{4}^{+}$-specific removal rate $\left(\mathrm{mg} \mathrm{N}-\mathrm{NH}_{4}^{+} / \mathrm{g} \mathrm{SV}\right.$ h) } \\
\hline & & $0-0.5 \mathrm{~h}$ & $0.5-1.25 \mathrm{~h}$ & $1.25-2 \mathrm{~h}$ & $2-2.75 \mathrm{~h}$ & $2.75-3.5 \mathrm{~h}$ & $3.5-4.25 \mathrm{~h}$ & Total \\
\hline 1 & 1 & & & & & & & \\
\hline 2 & 2 & & & & & & & \\
\hline 3 & 6 & 11.01 & 3.63 & 0.00 & 0.58 & 0.99 & 0.00 & 1.92 \\
\hline 4 & 9 & 7.40 & 0.50 & 3.72 & 0.99 & 0.25 & 0.00 & 1.82 \\
\hline 5 & 16 & 42.75 & 3.14 & 1.32 & 0.33 & 0.25 & 0.74 & 6.05 \\
\hline 6 & 20 & 7.90 & 0.74 & 3.63 & 4.21 & 0.74 & 0.50 & 2.66 \\
\hline 7 & 28 & 22.39 & 1.73 & 0.00 & 0.00 & 1.73 & 0.58 & 3.16 \\
\hline 8 & 35 & 1.38 & 7.27 & 0.33 & 1.57 & 2.97 & 2.64 & 2.77 \\
\hline 9 & 42 & 0.00 & 9.00 & 2.15 & 5.53 & 0.91 & 1.32 & 0.82 \\
\hline 10 & 49 & 0.00 & 0.00 & 1.40 & 2.73 & 2.73 & 0.00 & 1.15 \\
\hline 11 & 58 & 0.00 & 7.35 & 4.46 & 2.89 & 0.00 & 1.90 & 1.52 \\
\hline 12 & 62 & 0.00 & 4.29 & 0.33 & 1.40 & 4.54 & 3.22 & 2.04 \\
\hline 13 & 69 & 9.92 & 2.73 & 0.00 & 0.00 & 2.97 & 0.50 & 2.19 \\
\hline 15 & 83 & 4.03 & 0.65 & 1.11 & 2.81 & 3.33 & 0.59 & 1.97 \\
\hline Mean & & 8.81 & 3.30 & 1.44 & 1.82 & 1.82 & 1.04 & 2.32 \\
\hline
\end{tabular}

observed in the floc dimensions and sludge concentrations. In the batch tests, the average dimension of the flocks was comparable to that observed in conventional activated sludge. In the high pressure condition of the reactor, the flocks dimensions were smaller ( $47 \%$ of flocks had an average diameter of less than $150 \mu \mathrm{m}$ ). This effect was attributed to the stress conditions affecting the biomass. In the batch experiment, a large percentage of filamentous organisms were detected (particularly Micothrix) including ciliate, indicating an adequate dissolved oxygen concentration and distribution. In the reactor, the percentage of filamentous organisms was significantly lower, with a predominance of smaller flock dimensions and a lower sludge concentration.

\subsection{Results from the second experimental phase}

\subsubsection{COD removal efficiency}

Residual soluble COD, COD removal efficiencies and COD specific removal rates are plotted along with the biofilm thickness over time in Fig. 6. The specific removal rates were calculated using the volatile component of both the suspended $\left(\mathrm{VS}_{\mathrm{susp}}\right)$ and attached $\left(\mathrm{VS}_{\text {attach }}\right)$ biomass (from the second and third experimental phase).
The volatile solids in the suspended biomass $\left(\mathrm{VS}_{\text {susp }}\right)$ were measured during the experiments, whereas the volatile solids in the attached biomass $\left(\mathrm{VS}_{\text {attach }}\right)$ were calculated from the measured biofilm thickness and density.

As expected, the COD removal rate was high at the beginning of the tests (Table 4). Due to the lower concentration of the substrate, the slower diffusion within the biofilm resulted in a lower reaction rate. Specifically, the removal of the carbonaceous substrate primarily occurred within the first hour of treatment, after which the removal rate decreased, thus leading to residual soluble COD at the end of each run. The COD specific removal rates over time are reported in Table 4 . High removal efficiencies were obtained (average value was 91\%) with a final residual soluble COD mean value of $52.5 \mathrm{mg} / \mathrm{l}$ (Fig. 6). A slight decrease in the removal efficiencies after detachment of the biomass was observed (Fig. 6). Neither the carbonaceous removal efficiencies nor the residual soluble COD concentrations were significantly influenced by the detachment operations (most likely because of the contribution of the suspended biomass) or by an excessive biofilm growth (because of the limitation in the penetration of the substrates into the biofilm).

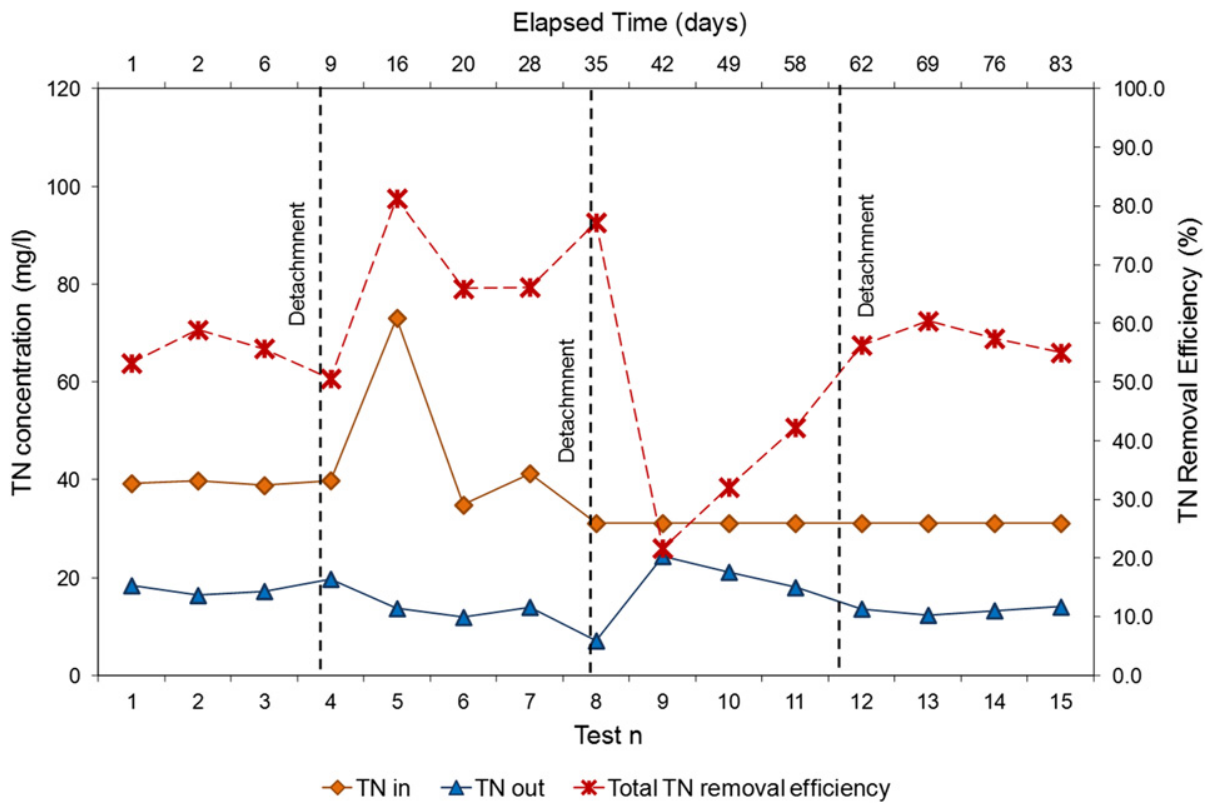

Fig. 8. The TN concentrations (influent and effluent) and removal efficiency in the attached biomass section (reactors AB1 and AB2). 


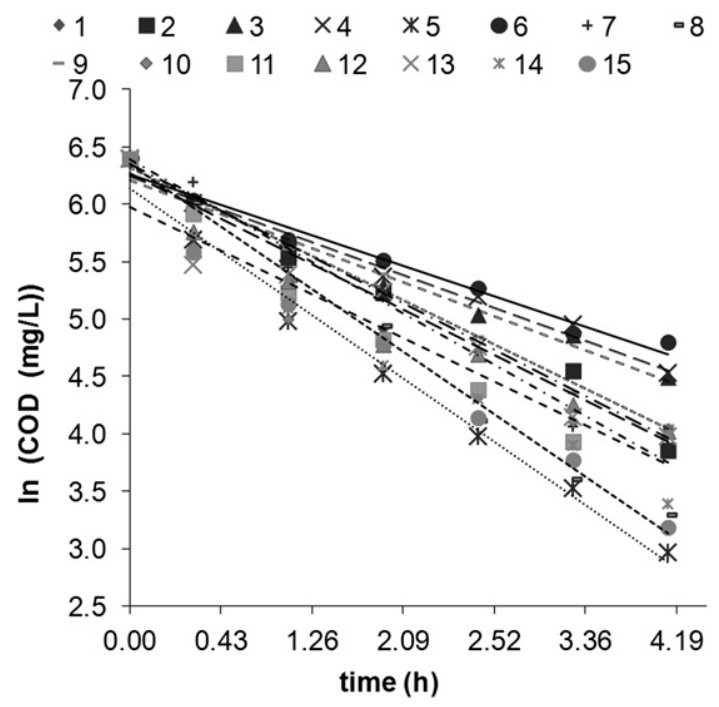

Fig. 9. Kinetic values for the COD removal in the attached biomass section (reactors $\mathrm{AB} 1$ and $\mathrm{AB} 2$ ).

\subsubsection{Nitrogen removal efficiency}

Residual $\mathrm{N}-\mathrm{NH}_{4}^{+}$, removal efficiencies, specific removal rates and biofilm thickness over time are reported in Fig. 7. In the same figure $\mathrm{N}-\mathrm{NO}_{3}$-concentration generated and measured in the effluent are presented to evidence the occurring denitrification process.

The nitrogen removal behavior was similar to that of the COD; indeed, higher removal rates were found in the upper section of the attached biomass reactor, whereas lower removal rates were observed in the deeper section. This was thought to be caused by the lower amount of nitrogen available in the liquid phase, which reduced the driving force for the penetration of the substrate into the biofilm. The $\mathrm{N}-\mathrm{NH}_{4}^{+}$specific removal rates are reported in Table 5 .

All of the tests highlighted the effective removal of the nitrogen substrate during operation, leading to a mean $\mathrm{N}-\mathrm{NH}_{4}^{+}$removal efficiency of 55\%. In contrast to what was observed for COD, the detachment action played an important role in nitrogen removal, as

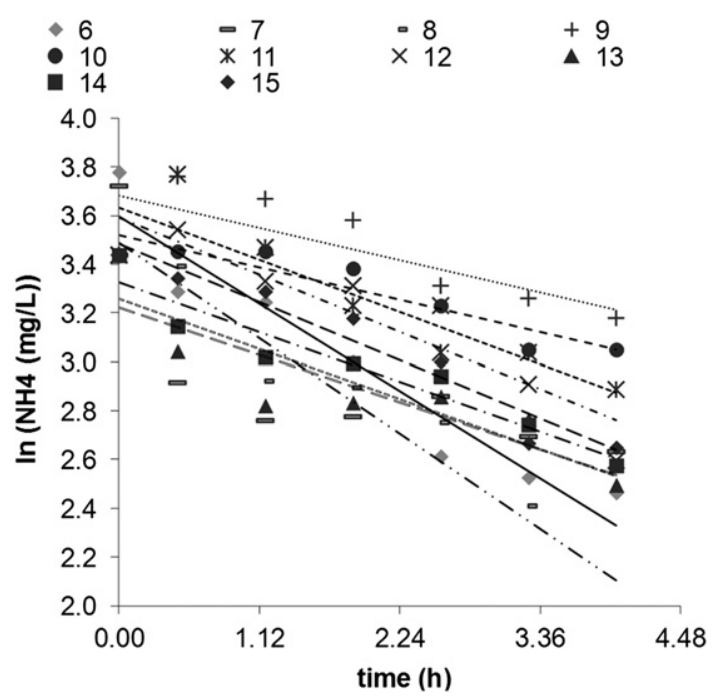

Fig. 10. Kinetic behavior for the removal of $\mathrm{N}-\mathrm{NH}_{4}^{+}$in the attached biomass section (reactors $\mathrm{AB} 1$ and $\mathrm{AB} 2$ ).

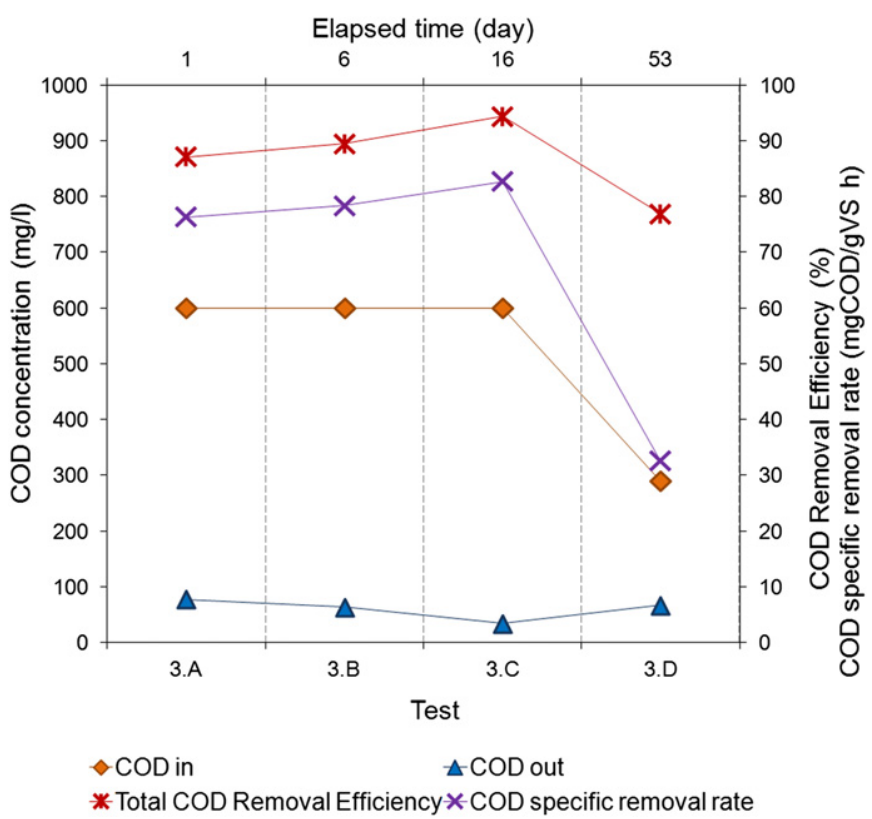

Fig. 11. COD removal efficiencies and specific removal rates.

a consequence of the lower growth rate of such biomass. Immediately after detachment, a reduction in nitrogen removal was observed (Fig. 7). This was due to different effects, such as the nitrifying biomass reduction and higher reaction times, that are required for the nitrification process. An increased removal rate was observed as new biofilm grew (Fig. 7). The nitrogen removal efficiency strongly depended on the characteristics of the stable active biofilm layer, so time was required after the detachment phase before optimal conditions were restored (Tijhuis et al., 1996). The average growth rate resulting from the test period was $4 \mu \mathrm{m} / \mathrm{h}$.

Fig. 8 shows the total nitrogen (TN) concentration in both the influent and effluent. The TN varied from 31.1 to $63.1 \mathrm{mg} / \mathrm{l}$ in the influent and from $7.1 \mathrm{mg} / \mathrm{l}$ to $23.4 \mathrm{mg} / \mathrm{l}$ in the effluent. The average TN concentrations of the influent and effluent were $37.1 \mathrm{mg} / \mathrm{l}$ and $15.7 \mathrm{mg} / \mathrm{l}$, respectively. The TN mass balance (determined by the differences between the influent and effluent TN concentrations), together with the $\mathrm{NO}_{3}^{-}$consumption (Fig. 7), showed an overall loss in nitrogen, which was due to the SND process occurring in the attached biomass system, as confirmed by Li et al. (2010). Some of the nitrates were thus reduced to nitrogen gas in the inner part of the biofilm due to the reduced penetration of oxygen and its consumption within the biofilm layer. The decrease in the TN removal efficiencies immediately after the detachment operations (Fig. 8) showed the dependence of the overall SND process on the biofilm dynamics (Wang et al., 2008). SND is related to the amount and activity of anaerobic microorganisms, which are indirectly controlled by the thickness of the anaerobic layer. After the biofilm

Table 6

COD specific removal rates for different contact times.

\begin{tabular}{|c|c|c|c|c|c|c|c|}
\hline \multirow[t]{2}{*}{ Test } & \multicolumn{7}{|c|}{ COD specific removal rate (mg COD/g VS h) } \\
\hline & $0-0.5 \mathrm{~h}$ & $0.5-1.25 \mathrm{~h}$ & $1.25-2 \mathrm{~h}$ & $2-2.75 \mathrm{~h}$ & $2.75-3.5 \mathrm{~h}$ & $3.5-4.25 \mathrm{~h}$ & Total \\
\hline $3 . A$ & 244.7 & 108.5 & 28.1 & 36.2 & 52.2 & 44.2 & 76.3 \\
\hline 3.B & 230.2 & 129.2 & 32.3 & 40.4 & 26.2 & 62.6 & 78.4 \\
\hline 3.C & 311.0 & 180.8 & 36.2 & 8.0 & 28.1 & 8.0 & 82.7 \\
\hline 3.D & 130.4 & 95.2 & 2.5 & 0.0 & 0.0 & 0.0 & 32.6 \\
\hline Mean & 229.1 & 128.4 & 24.8 & 21.1 & 26.7 & 28.7 & 67.5 \\
\hline
\end{tabular}


a

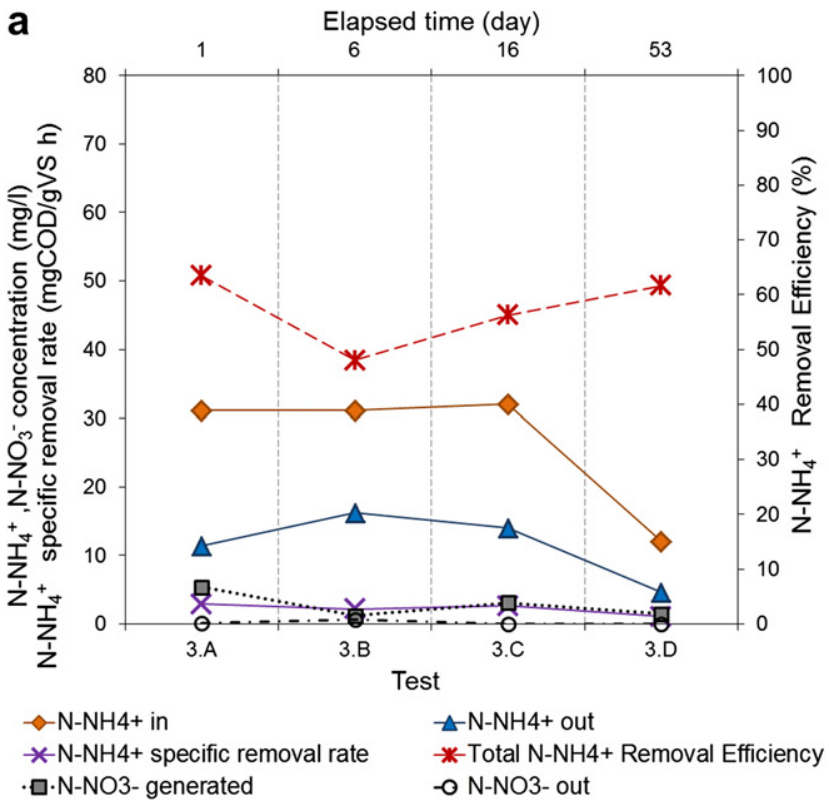

b Elapsed time (day)

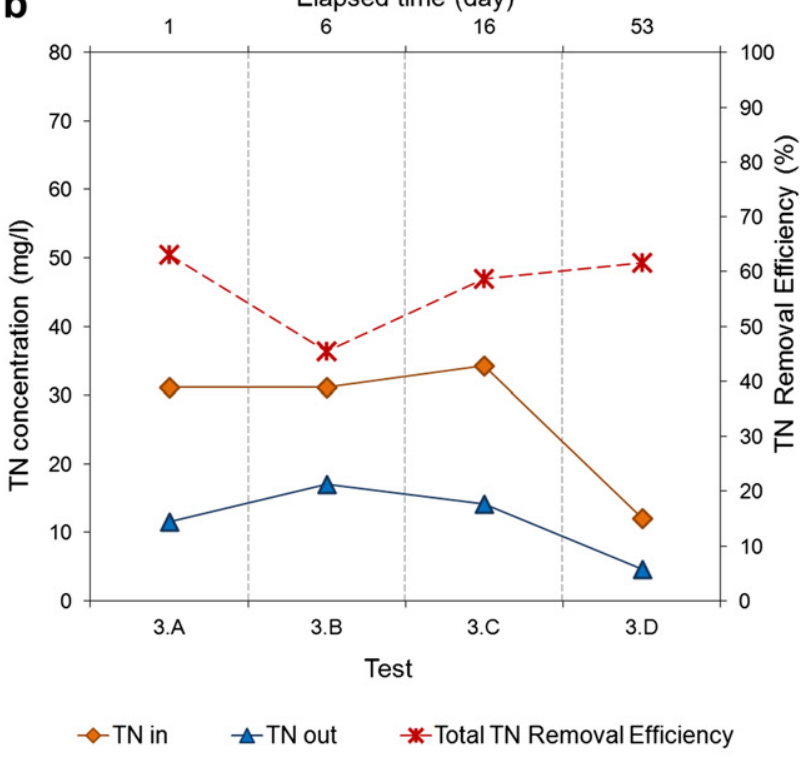

Fig. 12. Substrate trend (in the influent and effluent) and removal efficiency for: a) $\left.\mathrm{N}-\mathrm{NH}_{4}^{+}, \mathrm{b}\right) \mathrm{TN}$.

detachment, the reduced biofilm thickness allowed for a deeper penetration of oxygen, inhibiting the anoxic denitrification process.

\subsubsection{Removal kinetics}

The assumption of first-order removal kinetics for carbonaceous substrates, generally reported in the scientific literature, was confirmed by the experimental results (Fig. 9). The substrate utilization rate was, on average, $14.05 \mathrm{~d}^{-1}$.

The kinetic order for nitrification, in the case of the attached biofilm, ranges from zero to one (Henze et al., 2002). A different behavior was observed in the present experiments, as only a small fraction of the biomass behaved with such kinetics. The inner regions can follow different processes (as in the case of concentrations lower than Ks), which, in the evaluation of the overall kinetic behavior, can lead to the identification of a first-order reaction (Fig. 10). The substrate utilization rate for the nitrification process was found to be $4.8 \mathrm{~d}^{-1}$.

When nitrogen is not the limiting factor (the rate of substrate utilization is zeroth order), the nitrification rate will primarily depend on the oxygen concentration. However, when the nitrogen concentration decreases below $2-4 \mathrm{mg} / \mathrm{l}$, the nitrification rate can be assumed to be first order, and the limiting factor becomes the diffusion of the nitrogen substrate into the biofilm.

\subsection{Results from the third experimental phase}

\subsubsection{COD removal efficiency}

The residual COD, removal efficiencies and specific removal rates are reported in Fig. 11. Analysis of the efficiencies shows that the pressure does not affect the performances of the system. The removal efficiencies were always high, with an average of $87 \%$. The COD consumption occurs mainly in the upper part of the reactor, where it is degraded by heterotrophic attached biomass and used in nitrate removal, so the expected lower efficiency at the adopted higher pressures can be neglected. The results, summarized in Table 6, show a mean specific removal rate of $230 \mathrm{mg}$ COD/g VS h in the first $30 \mathrm{~min}$, which decreases in the following hours. The specific removal rates were calculated using the volatile component of both suspended ( $\left.\mathrm{VS}_{\text {susp }}\right)$ and attached ( $\left.\mathrm{VS}_{\text {attach }}\right)$ biomass.
The mean values of VS was $1.61 \mathrm{~g} / \mathrm{l}$, while the mean biofilm thickness was $1.21 \mathrm{~mm}$.

\subsubsection{Nitrogen removal efficiency}

Residual $\mathrm{N}-\mathrm{NH}_{4}^{+}$, total removal efficiencies and specific removal rates are reported in Fig. 12a.

During the first hour, the removal rate of the ammonia nitrogen substrate was particularly high, and after this hour, the removal rate decreased (Table 7 ). The experimental results show a mean specific consumption rate of $6.8 \mathrm{mg} \mathrm{N}-\mathrm{NH}_{4}^{+} / \mathrm{g} \mathrm{VS}$ h in the first $30 \mathrm{~min}$, which dropped to $1.6 \mathrm{mg} \mathrm{N}-\mathrm{NH}_{4}^{+} / \mathrm{g}$ VS $\mathrm{h}$ in the last period (Table 7).

The mean removal efficiency was $57 \%$, and the total $\mathrm{N}-\mathrm{NH}_{4}^{+}$ specific removal rate was $2 \mathrm{mg} \mathrm{N}-\mathrm{NH}_{4}^{+} / \mathrm{g} \mathrm{SSV}$ h (Fig. 12a).

The mass balance of total nitrogen for the entire integrated system (Fig. 12b) together with the $\mathrm{NO}_{3}^{-}$consumption (Fig. 12a), also indicates a simultaneous nitrification and denitrification process, resulting in almost complete substrate removal. The TN varied from 12 to $32.1 \mathrm{mg} / \mathrm{l}$ in the influent and from 5 to $17 \mathrm{mg} / \mathrm{l}$ in the effluent. The average TN concentration of the influent and effluent were $27 \mathrm{mg} / \mathrm{l}$ and $12 \mathrm{mg} / \mathrm{l}$, respectively.

\subsubsection{Overall treatment performances}

Table 8 shows a comparison of the typical features and related performances of a conventional activated sludge (CAS) process (Zhou et al., 2003), a BAS reactor (Zhou et al., 2003) and the integrated system proposed in this work. The proposed system allows for carbonaceous removal efficiencies comparable with those

Table 7

Specific removal rates of $\mathrm{N}-\mathrm{NH}_{4}^{+}$for different contact times.

\begin{tabular}{|c|c|c|c|c|c|c|c|}
\hline \multirow[t]{2}{*}{ Test } & \multicolumn{7}{|c|}{$\mathrm{N}-\mathrm{NH}_{4}^{+}$specific removal rate $\left(\mathrm{mg} \mathrm{N}-\mathrm{NH}_{4}^{+} / \mathrm{g} \mathrm{VS} \mathrm{h}\right.$ ) } \\
\hline & $0-0.5 \mathrm{~h}$ & $0.5-1.25 \mathrm{~h}$ & $1.25-2 \mathrm{~h}$ & $2-2.75 \mathrm{~h}$ & $2.75-3.5 \mathrm{~h}$ & $3.5-4.25 \mathrm{~h}$ & Total \\
\hline 3.A & 3.78 & 2.20 & 3.66 & 5.54 & 1.46 & 0.94 & 2.88 \\
\hline 3.B & 5.35 & 0.63 & 5.02 & 0.63 & 0.21 & 2.30 & 2.18 \\
\hline 3.C & 12.39 & 3.72 & 1.41 & 0.66 & 0.25 & 0.58 & 2.63 \\
\hline 3.D & 5.46 & 1.99 & 0.00 & 0.00 & 0.33 & 0.17 & 1.08 \\
\hline Mean & 6.75 & 2.13 & 2.52 & 1.71 & 0.56 & 1.00 & 2.19 \\
\hline
\end{tabular}


Table 8

Comparison of a conventional activated sludge (CAS) process, BAS reactor and the proposed integrated system. ${ }^{\mathrm{a}}$

\begin{tabular}{|c|c|c|c|c|c|c|c|c|c|c|c|}
\hline & \multirow[t]{2}{*}{ HRT (h) } & \multicolumn{2}{|l|}{ Influent } & \multicolumn{2}{|l|}{ Effluent } & \multicolumn{2}{|c|}{ Removal efficiency } & \multirow{2}{*}{$\begin{array}{l}X \\
\left(\text { g VSS L }^{-1}\right)\end{array}$} & \multicolumn{2}{|c|}{ Specific removal rates } & \multirow{2}{*}{$\begin{array}{l}\mathrm{Nv} \\
\left(\mathrm{kg} \operatorname{COD} / \mathrm{m}^{3} \mathrm{~d}\right)\end{array}$} \\
\hline & & $\begin{array}{l}\mathrm{COD} \\
\left(\mathrm{mg} \mathrm{L}^{-1}\right)\end{array}$ & $\begin{array}{l}\mathrm{NH}_{4}^{+} \\
\left(\mathrm{mg} \mathrm{L}^{-1}\right)\end{array}$ & $\begin{array}{l}\mathrm{COD} \\
\left(\mathrm{mg} \mathrm{L}^{-1}\right)\end{array}$ & $\begin{array}{l}\mathrm{NH}_{4}^{+} \\
\left(\mathrm{mg} \mathrm{L}^{-1}\right)\end{array}$ & $\begin{array}{l}\text { COD } \\
(\%)\end{array}$ & $\begin{array}{l}\mathrm{NH}_{4}^{+} \\
(\%)\end{array}$ & & $\begin{array}{l}\text { COD } \\
(\mathrm{mg} \mathrm{COD} / \mathrm{g} \text { VSS h) }\end{array}$ & $\begin{array}{l}\mathrm{N}-\mathrm{NH}_{4}^{+} \\
\left(\mathrm{mg} \mathrm{N}-\mathrm{NH}_{4+} / \mathrm{g} \text { VSS h}\right)\end{array}$ & \\
\hline $\begin{array}{l}\text { CAS (Zhou } \\
\text { et al., 2003) }\end{array}$ & $4-8$ & & & & & $>90 \%{ }^{\mathrm{b}}$ & & $1.5-3$ & & & $0.8-1.6$ \\
\hline $\begin{array}{l}\text { BAS (Zhou } \\
\text { et al., 2003) }\end{array}$ & 1.0 & 217.0 & 14.2 & 27.0 & 6.8 & 87.6 & 52.4 & 5.62 & 33.84 & 1.33 & 4.95 \\
\hline $\begin{array}{l}\text { Integrated } \\
\text { BAS system }\end{array}$ & 4.0 & 600.0 & 31.4 & 58.4 & 13.9 & 90.3 & 55.9 & 3.17 & 80.4 & 2.60 & 3.6 \\
\hline
\end{tabular}

${ }^{\text {a }}$ Results for the proposed integrated BAS system are referred to as test 3B, 3C and 3D.

b For BOD 5.

obtained in a CAS system, but with higher organic loads and lower space requirements. When compared with the BAS system, the present treatment shows comparable removal efficiencies and higher specific removal rates. It is important to highlight the fact that the proposed solution combined the discussed advantages with nitrogen removal (as evidenced by the observed SDN), thus representing a sustainable and alternative wastewater treatment process that is characterized by high efficiency, low required volumes and easy separation of the suspended solids.

\section{Conclusions}

A compact and efficient system is presented as alternative to conventional domestic wastewater treatment systems. The low volume requirement, low odor (high DO content in the sludges) and high quality of the effluent in terms of the SS (flotation) are the main advantages of the proposed system. The use of attached biomass allows for high sludge retention times for complete nitrogen removal. The typical substrates of domestic sewage are treated with optimal efficiencies. The proposed integrated system produced the following average values for the removal efficiencies: $90 \%$ for the COD and $56 \%$ for $\mathrm{N}-\mathrm{NH}_{4}^{+}$.

The majority of the COD consumption occurs in the upper part of the attached biomass in the reactor, and nitrification, characterized by a lower rate of removal, occurs when the COD concentration is decreased. The observed $\mathrm{NO}_{3}^{-}$removal occurred in the deeper part of stratified biofilm when nitrates were formed and COD was still available.

Denitrification is mainly managed by the limited penetration of DO into the biofilm. DO is consumed during both the oxidation and nitrification processes, and the anoxic region of the biofilm is devoted to the removal of nitrates.

The $\mathrm{NH}_{4}^{+}$removal rates depend on the active biofilm thickness as shown from the detachment phase consequences.

The suspended biomass, present in the deeper part of the reactor, plays an important role in the overall treatment by acting as a sort of effluent finishing However, the results from the first experimental phase, the study of the effects of increasing the operational pressure on the kinetics of the biological reaction, demonstrated the influence of high pressures on the removal of the carbonaceous substrate due to the particular sensitivity of the heterotrophic bacteria to altered environmental conditions. The effect of high pressures on the entire system is negligible due to the high COD consumption in the upper part of the reactor, where the pressures are not as high.

A comparison of the parameters of conventional activated sludge and BAS processes with the proposed system shows that this proposed system can be a promising wastewater treatment process with high efficiency, low odor, low required volumes and an easy and efficient separation system for the suspended solids.

The results presented in this paper, together with the development of a numerical model for the process description, comprise work that has been used in the complete design of a full-scale treatment plant realized in Italy (Abbadia S. Salvatore, SI).

\section{References}

Del Pozo, R., Diez, V., 2005. Integrated anaerobic-aerobic fixed film reactor for slaughterhouse wastewater treatment. Water Res. 39, 1114-1122.

Eaton, A.D., American Public Health Association, American Water Works Association, Water Environment Federation, 2005. Standard Methods for the Examination of Water and Wastewater, 21st ed. APHA-AWWA-WEF, Washington D.C.

Garrido, J.M., Campos, J.L., Méndez, R., Lema, J.M., 1997. Nitrous oxide production by nitrifying biofilms in a biofilm air lift suspension reactor. Wat. Sci. Tech. 36 (1), 157-163.

Guo, H., Zhou, J., Su, J., Zhang, Z., 2005. Integration of nitrification and denitrification in air lift bioreactor. Biochem. Eng. J. 23, 57-62.

Henze, M., Harremoes, P., la Cour Jansen, J., Arvin, E., 2002. Wastewater Treatment: Biological and Chemical Processes, third ed. Springer, Verlag Berlin Heidelberg.

Li, Z.H., Yang, K., Yang, X.J., Li, L., 2010. Treatment of municipal wastewater using a contact oxidation filtration separation integrated bioreactor. J. Environ. Manage. 91 (5), 1237-1242.

Mancini, G., Barone, C., Roccaro, P., Vagliasindi, F.G.A., 2007. The beneficial effects of storage on the quality of wastewater for irrigation: a case study in Sicily. Water Sci. Technol. 55 (1-2), 417-424.

Nicolella, C., van Loosdrecht, M.C.M., Heijnen, J.J., 1998. Mass transfer and reaction in a biofilm airlift suspension reactor. Chem. Eng. Sci. 53 (15), 2743-2753.

Nicolella, C., van Loosdrecht, M.C.M., Heijnen, J.J., 2000a. Wastewater treatment with particulate biofilm reactors. J. Biotechnol. 80, 1-33.

Nicolella, C., Van Loosdrecht, M.C.M., Heijnen, S.J., 2000b. Particle-based biofilm reactor technology. Tibtech $18,312-320$.

Ong, S.L., Liu, Y., Lee, L.Y., Hu, J.Y., Ng, W.J., 2004. A novel high capacity biofilm reactor system for treatment of domestic sewage. Water Air Soil Pollut. 157, 245-256.

Tijhuis, L., Hijman, B., Van Loosdrecht, M.C.M., Heijnen, J.J., 1996. Influence of detachment, substrate loading and reactor scale on the formation of biofilms in airlift reactors. Appl. Microbiol. Biotechnol. 45, 7-17.

Tomaszek, J.A., Grabas, M., 1998. Biofilm reactors: a new form of wastewater treatment. In: Pawlowski, et al. (Eds.), Environmental Science Research Chemistry for the Protection of the Environment, vol. 55 (3). Plenum Press, p. 116.

Verlicchi, P., Masotti, L., Galletti, A., 2011. Wastewater polishing index: a tool for a rapid quality assessment of reclaimed wastewater. Environ. Monit. Assess. 173, 267-277.

Walters, E., Hille, A., He, M., Ochmann, C., Horn, H., 2009. Simultaneous nitrification/ denitrification in a biofilm airlift suspension (BAS) reactor with biodegradable carrier material. Water Res. 43, 4461-4468.

Wang, J.L., Peng, Y.Z., Wang, S.Y., Gao, Y.Q., 2008. Nitrogen removal by simultaneous nitrification and denitrification vias nitrite in a sequence hybrid biological reactor. Chin. J. Chem. Eng. 16, 778-784.

Zhang, X., Zhou, J., Guo, H., Qu, Y., Liu, G., Zhao, L., 2007. Nitrogen removal performance in a novel combined biofilm reactor. Process. Biochem. 42, 620-626.

Zhou, P., He, J., Qian, Y., 2003. Biofilm airlift suspension reactor treatment of domestic wastewater. Water Air Soil Pollut. 144 (1-4), 81-100. 